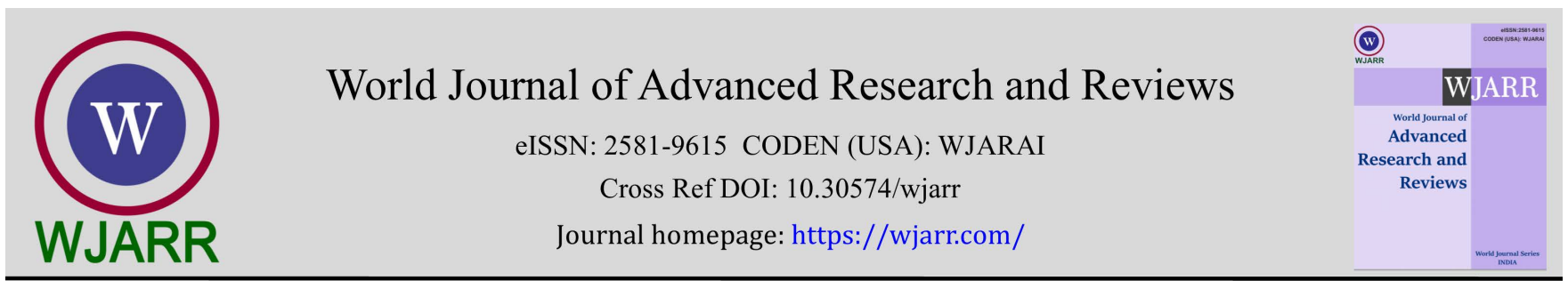

(RESEARCH ARTiClE)

\title{
Effect of internet banking on the performance of small-medium enterprises in Enugu metropolis
}

\author{
Maureen Ifeoma Iyke-Ofoedu ${ }^{1}$, Onodugo Ifeoma Joanes ${ }^{1}$ and Umeh Anthony Chinedu ${ }^{2, *}$ \\ ${ }^{1}$ Management Department; University of Nigeria, Enugu Campus. \\ 2 Department of Economics, Enugu State University of Science and Technology.
}

World Journal of Advanced Research and Reviews, 2022, 13(02), 264-273

Publication history: Received on 08 January 2022; revised on 10 February 2022; accepted on 12 February 2022

Article DOI: https://doi.org/10.30574/wjarr.2022.13.2.0150

\begin{abstract}
The study examined the effect of internet banking on small and medium enterprises performance in Enugu Metropolis. Specifically this study aims to determine the (i) the effect of internet effectiveness on small and medium enterprises business expansion in Enugu Metropolis, and (ii) the effect of internet convenience on small and medium enterprise quality of job delivery in Enugu Metropolis. The study made use of descriptive survey design. The study used structured questionnaire to obtain data. The population of the study is 650 with sample size of 264 . Summary of the study includes: the findings of the study revealed that internet effectiveness has significant effect on small and medium enterprises business expansion in Enugu metropolis ( $\mathrm{t}$ - statistics (38.887) > P - value (0.000), the findings of the study also revealed that internet convenience has significant effect on small and medium enterprise quality of job delivery in Enugu metropolis $(\mathrm{t}$ - statistics $(33.446)>\mathrm{P}$ - value $(0.000)$, and the findings of the study revealed that internet accessibility has significant effect on small and medium enterprise expansion of income base in Enugu metropolis, because internet accessibility enables to conduct banking business over the internet where costs are minimal, since ( $t$ - statistics (51.826) > P - value (0.000). The study recommends that small and medium enterprises should organize training on internet banking from time to time for the benefit of its customers; this will go a long way to enhance the benefits derived by the bank from internet banking.
\end{abstract}

Keywords: Internet Banking; Small and Medium Enterprises Performance

\section{Introduction}

\subsection{Background of the Study}

The banking industry of the 21st century operates in a complex and competitive environment characterised by changing conditions and a highly unpredictable economic climate. This is due to in a large extent comes as a result of technological improvement, increased awareness and demands that banks serve their customers electronically. Internet banking is a service of electronic banking (e-banking). It enables bank customers to access accounts and generate information on bank products and services through the internet. This can be at the comfort of their homes or offices. However, banking through internet has emerged as a strategic resource for achieving higher efficiency, control of operations and reduction of cost by replacing paper based and labour intensive methods with automated processes thus leading to higher productivity and profitability. Nonetheless, recent empirical studies indicate that Internet banking is not having an independent effect on banking profitability, although these findings may change as the use of the Internet becomes more widespread. Internet banking in banks ensured that performance of banks improved more than when banks were using traditional system of banking in the organization.

\footnotetext{
* Corresponding author: Umeh Anthony Chinedu

Department of Economics, Enugu State University of Science and Technology.

Copyright (C) 2022 Author(s) retain the copyright of this article. This article is published under the terms of the Creative Commons Attribution Liscense 4.0.
} 
The introduction of internet banking in the bank ensures that banks operate at a cheaper cost, have 24 hours internet service availability as well as encourage ICT competence of customers in order to realized high performance in terms of organizational effectiveness, efficiency and business expansion. This view is supported by Abubakar [1] who explained that internet banking has the potentials to improve productivity, growth and profitability performance of banks due to low cost advantages associated with the delivery of its services .Again industry analysis outlining the potential effect of internet banking on cost savings, revenue growth and risk profile of the banks have also generated considerable interest and speculation about the effect of the internet on the banking industry [2].

Internet banking is very common in everyday transactions and is no longer something new methods of accessing banking. With the Internet increasingly accessible as well as the development of growth will be the use of internet banking, it can be seen the extent to which the importance of the quality provided by the bank. Where the Internet can be used as a medium to find information about products and competitors, as well as to what is in demand by consumers outside [3]. The technology needed continuously in the process of business operations is complementary in producing a quality product with an effective and efficient process. An effort needs to be made on performance measurement as a basis for how high achievement of productivity. Basically internet banking was made in order to facilitate the two sides, between the customer and the bank. Here are some of the benefits of Internet Banking for the customer and the bank. By using the Internet Banking facility actually benefit the customer. The benefits of internet banking for such customers are customers no longer need to visit the bank to conduct banking transactions. Thus, customers benefit in terms of time and cost. Increase the performance through saving all tacit knowledge from their potential workers. Especially in service industry like banking, where most knowledge obtained from experience while serving clients, to achieve its best performance, service industry should put knowledge management as a standard. Identifying of profile and banking habits as well as their awareness, usage, is important to influence degree of satisfaction, included factors of determining customers like friendliness of bank personnel and caring attitude toward customers [4]. Therefore, the concern of this study is to verify the relationship between internet banking and performance of small-medium enterprises, the direction of relationship between internet banking and performance of small-medium enterprises if any exist and the characteristic of internet banking that contributes most to performance of small-medium enterprises in Enugu metropolis.

\subsection{Statement of the Problem}

The major problems of this study is that internet banking has replaced human with technology and hardly guarantees customers trust due to network failure. Internet banking is essential not only for the development of smaller enterprises but the overall economy of any nation. A large number of internets banking on SMEs fail to attain maturity and a number of them eventually die with estimates ratio given at five in ten per year. The reason(s) for these internet banking on SMEs failures are unknown to business managers. These failures and eventual collapse are known to be caused by internal and external factors among which are poor management skills, lack of finance, poor preparation, poor knowledge of the sector and its value chain, etc. Others include poor accounting and book-keeping, lack of production manuals, minimal or no quality control, and raw materials sourcing which are responsibilities of the owner.

Another often neglected cause of internet banking on SME failures is staff challenges. It is impossible for the owner to do everything, there is a need to engage the services of employees, but rather than aid progress, they become cogs in the wheel of progress, and without a substantial input from the business owners, what started as a viable business may fail within weeks or months. Another factor is that most start-ups internet banking on SME lacks the underlying training to engage what they do. Most people start internet banking on SMEs because they have unlimited cash flow and feel like starting a business. Challenges arise in the cours e of running the business, and lack of required training makes the business derail. New business entrants underestimate the importance of training and/or experience before venturing into business. The use of mobile phones can be said to be transformative, and aids in expanding financial access to the rural population but much is still needed to be done. Information is of utmost importance to every successful business. But the lack of useful and adequate information has led to the collapse of many start-ups across the world. The low rate of internet penetration and usage in developing economies such as Nigeria poses a more significant threat to start-ups. For competitive advantage, prices, nearness of raw materials, and competitors, SWOT are considered before venturing into business. The lack or unavailability of information requires that new entrants dig deeper into the factors that necessitate consumers' choice of a product and service. These will equip them with areas of concentration pertaining to customers' demands. Against these backdrops, this study aimed to examine the effect of internet banking on the performance of small-medium enterprises in Enugu metropolis. 


\section{Objectives of the Study}

The main objective of this study is to examine the effect of internet banking on the performance of small-medium enterprises in Enugu metropolis. The specific objectives of this study are to:

- $\quad$ examine the effect of internet banking effectiveness on small and medium enterprises business expansion in Enugu Metropolis.

- $\quad$ evaluate the effect of internet banking convenience on small and medium enterprise quality of job delivery in Enugu Metropolis.

\subsection{Conceptual Review}

\subsubsection{Internet Banking}

Internet Banking offers several types of services through which customers of the bank can request for, get information and can also carry out most of their banking transactions through their smart devices and computers [5]. Chang and Hamid [6] defined Internet Banking as the process through which customers complete banking transactions electronically without visiting the banks physically or without visiting brick and mortar bank. Alsajja and Dennis [7] defined Internet Banking as the process of providing banking services through technology without using physical resources of banks as well as staff. According to Gerrard and Cunningham [8] Internet Banking is defined as the usage of Internet and Telecommunication networks to deliver banking services to customers. Kim, Widdows, Yilmazer, [9] defined Internet Banking as the process whereby the customer is able to access, control and use his or her account over the Internet. They described Internet Banking as the act of conducting financial intermediation on the internet. According to Arunachalam and Sivasubramanian [10], Internet Banking is where a customer can access his or her bank account via the Internet using personal computer (PC) or mobile phone and web-browser.

\section{Small and medium enterprises (SMES) performance}

A thriving small and medium entrepreneurship sector is made up of providers of a prosperous and strong economy. Small and medium enterprises (SMEs) performance has a significant weight in the growth of the economy of a country. Small and Medium Enterprises (SMEs) performance contribute to economic progress in numerous ways: by providing job opportunities for rural and urban areas, supporting required sustainability and innovation, supplying products and services in the economy as a whole. A large number of people rely on the small and medium enterprises and most of the current larger enterprises have started as SMEs [11].

The level of development in each country has also an effect on the small and medium entrepreneurship sector. The difference among contributions in terms of economic results and the employment rate in SMEs in low and high-income countries is noteworthy. SMEs in high-income countries account for more than 51 percent of GDP and 57 percent of employment, while in low income countries, this figure slightly rises above 20 percent of both GDP and employment rate. However, leading providers of economic dynamism are the unregistered microenterprises that comprise the "informal sector" which has a greater share [12]. Performance in this regard (on the macro level) is the factor that defines the contribution level of SMEs to the economy. Consequently, this phenomenon is another point that requires more attention to the performance of SMEs on the micro level as well.

Again, the current context of rapid changes in the world economy, the interdependencies between national economies (a direct effect of globalisation) and a difficult recovery after the global economic crisis have meant that the role of SMEs has significantly increased, based on their ability to adapt to challenges of a continuously changing environment [13]. Also, SMEs represent the framework of free entrepreneurial initiative and entrepreneurship, vital elements defining a competitive economy [14]. Although with different intensities (from one economy to another, from one geographic area to another or from one entrepreneurial culture to another), it was found that SMEs play a major part in the process of promoting technical progress in society and innovation in economic activity

\subsection{Theoretical Framework}

\subsubsection{Transactions Cost Innovative Theory}

The transaction cost innovation theory pioneered by Niehans cited in Mbah, Obiezekwem [15] advocated that the dominant factor of financial innovation is the reduction of transaction cost, and in fact, financial innovation is the response of the advance in technology which caused the transaction cost to reduce. The reduction of transaction cost can stimulate financial innovation and improvement of financial service. It states that financial innovation reduces 
transaction costs. Transaction costs Innovation theory is also relevant in this context: for instance, the use of Internetconnected Information Technology (IT) can substantially reduce a firm's transaction costs as it enables efficient coordination, management and use of information. Mobile, Internet-connected IT may further lower transaction costs as it provides also off-site access to the firm's internal database and other relevant sources of information. Consequently, reduction of operation costs through agency banking, internet banking and mobile banking may influence growth in profitability for the bank.

\subsection{Empirical Review}

Njoku, Nwadike, and Azuama, [16] conducted a study to examine the effect of electronic banking on the economic growth of Nigeria (2009-2018). Specifically this study aims to examines the impact of electronic banking on economic growth in Nigeria over the period of 2009 - 2018 using quarterly data. Method of data analyses used is distribution of questionnaires and secondary data were collected from the CBN statistical bulletin and the Nigerian Bureau of statistics. The study also adopted the Vector Error Correction Model (VECM) and the results of the analysis show that electronic banking has significantly impacted on the economic growth of Nigeria. The result of the analysis shows that Electronic Banking has a significant relationship with Nigeria's economic growth, while Point of Sales, Internet Banking and Mobile Banking, individually have no significant effect on Nigeria's economic growth, while Automated Teller Machine has significant effect on economic growth in Nigeria for the period under consideration. The study recommends that the government should reduce the charges on the use of electronic means of transactions so as to encourage people to use them more often.

Orga, Ibeme, and Ekwochi, [13] conducted a study to examine an overview of the Challenges and Survival Strategies of Small Scale Businesses in Enugu Metropolis (A Study of Selected Small Scale Businesses). Specifically this study aims to examine an overview of Challenges and Survival Strategies of Small Scale Businesses in Enugu Metropolis. Method of data analysis used is descriptive design. The findings of the study showed that despite some challenges faced by Small Scale Businesses that there are prospects through various strategies which has led to their survival. The study recommended that the government of Nigeria should create enabling environment that will lead to survival and growth of small scale businesses.

Mbah, and Obiezekwem, [15] conducted a study to examined the electronic banking and performance of small and medium scale enterprises in Anambra State, Nigeria. Specifically this study aims to identify the relationship between electronic banking and performance of small and medium scale enterprises in Anambra state; one of the states with the highest number of SMEs, entrepreneurial skills, informal enterprises and a suitable business environment in Nigeria. Also to achieve this, the researcher examined performance of SMEs and their association with components of electronic banking; automated teller machine, point of sale services, transaction alerts via short message services (SMS) and mobile banking. The study used SPSS and Excel to identify the descriptive characteristics of the variables of the study and analyze the data. Regression analysis was used to test the hypotheses of the study. The findings of this study shows that there is positive relationship between; automated teller machine, point of sale services, transaction alerts via short message services (SMS), mobile banking and performance of SMEs in Anambra State, Nigeria. The result also showed that SMEs continuous usage of electronic banking services could be attributed to cost effectiveness, convenience, security, accessibility and diversity of the services. The study recommends among others that, security of electronic banking services should be upgraded by a conjunction between SMEs and banks and that government should provide adequate regulatory framework to protect customers and security of transaction. Also, policy makers in Nigeria should take advantage of the positive revelation of this study to make policies that will increase number of SMEs in Anambra state and Nigeria at large especially from the large number of informal enterprises in Anambra state and Nigeria.

Dedi, Agil, and Putri [17] conducted a study to analyze the effect of internet banking on E-Commerce. Specifically this study aims to analyze how internet banking can significantly influence the development of e-commerce, which can actually reduce or not change the development of e-commerce in Indonesia. The method used in this research was the Case Study research method that aims to explain what is being investigated in this case and examine how this case can occur and develop in today's society. The findings of the study shows that internet banking can increase sales and expansion of research because with internet banking all customers experience difficulties such as far from nearby ATMs or banks and therefore can only be overcome with smartphones and a stable internet connection. The study recommends that internet banking can have a real influence on e-commerce development if properly administered.

Masocha and Dzomonda [18] studied the adoption of mobile money services and the subsequent performance of Small and Medium Enterprises (SMEs) in Zimbabwe. This contribution used the quantitative research method with a descriptive research design. The results indicated that benefits of mobile money and challenges in traditional financial 
services influenced firm adoption of mobile money services. Conclusively, the study established that subsequent adoption of mobile money services has an influence on the performance of SMEs.

Muchiri, [19] conducted a study to determine the effect of mobile banking adoption on the performance of small and medium enterprises in Nairobi country. Specifically this study aims at determining the magnitude to which small and medium enterprises have adopted mobile banking in Nairobi County, to establish the magnitude to which SMEs utilize the different services offered by the mobile banking and to establish the association between usage of m-banking services and SME performance. The method of data analysis used in this study is descriptive type of survey design. The targeted population of the study is 176. The findings of the study show that ease of use, cost effectiveness, convenience; security of the service, accessibility and diversity has enabled SMEs to continue to use mobile banking services. The finding also shows that mobile banking has increased customer base because of easy method of payments, more time to carry out other business activities, easy access to funds in the bank, increased business transactions, increased profits and increased business efficiency. The finding also shows that mobile banking adoption positively influences SME spar for mince in the county of Nairobi. The study recommended that SMEs to adopt m-banking services in their organizations. In this way the organization will be adopting the changing technologies so that to remain competitive.

\section{Methodology}

Study Area was Enugu State, Nigeria. The study made use of descriptive survey design. The study used structured questionnaire to obtain data. The choice of location was based on proximity, effective coverage and cost minimization. The population of study comprises the staffs of small and medium enterprises in Enugu metropolis. The selected small and medium enterprises in Enugu metropolis were Accurate Consult Institute, Transfiguration Biz. Centre, Trinity Business Complex, JAMA Venture, NATECH venture and Cascamite Glue Ltd. The sample size of 264 respondents was drawn from population of the study which consists of 6050 employees small and medium enterprise in Enugu Metropolis. Research questions were answered using frequency, mean and standard deviation. The hypotheses stated were tested using single regression.

\subsection{Data Presentation}

Table 1 Comprehensive Demographic of Respondents

\begin{tabular}{|c|c|c|}
\hline $\begin{array}{c}\text { Title } \\
\end{array}$ & Frequency & Percentage \\
\hline \multicolumn{3}{|l|}{ Questionnaire Distribution } \\
\hline Questionnaires Distributed & 264 & $100 \%$ \\
\hline Returned Questionnaires & 240 & $94 \%$ \\
\hline Not Returned Questionnaires & 24 & $6 \%$ \\
\hline \multicolumn{3}{|l|}{ Gender } \\
\hline Female & 170 & $55 \%$ \\
\hline Male & 94 & $45 \%$ \\
\hline \multicolumn{3}{|l|}{ Age Bracket } \\
\hline 21-30 Years & 130 & $39 \%$ \\
\hline $31-40$ Years & 80 & $32 \%$ \\
\hline $41-50$ Years & 49 & $20 \%$ \\
\hline 51Years - above & 5 & $9 \%$ \\
\hline \multicolumn{3}{|l|}{ Marital Status } \\
\hline Married & 107 & $55 \%$ \\
\hline Single & 65 & $31 \%$ \\
\hline Widow/widower & 47 & $9 \%$ \\
\hline Divorce & 45 & $5 \%$ \\
\hline
\end{tabular}

Two hundred and sixty four (264) copies of questionnaires were designed and distributed to the respondents. Out of the 264 Questionnaires distributed, 240 (94\%) were completed and returned while 24 (6\%) were not returned. 
Therefore, 94 percent respondents were a good representation. The study showed the respondents profile in frequency and percentage distribution of gender, age bracket and marital status.

\subsection{Data Analysis}

Question One: What is the extent at which internet effectiveness influences small and medium enterprises business expansion in Enugu metropolis?

Table 2 Mean rating of responses of respondents on the extent at which internet effectiveness influences small and medium enterprises business expansion in Enugu metropolis

\begin{tabular}{|c|c|c|c|c|c|c|c|c|c|}
\hline $\mathrm{S} / \mathrm{N}$ & Questionnaire Item & VHE(5) & HE(4) & $M(3)$ & LE(2) & VLE(1) & Total & Mean & SD \\
\hline \multirow[t]{3}{*}{1} & \multirow{3}{*}{$\begin{array}{l}\text { There is an extended } \\
\text { client base as a result of } \\
\text { internet effectiveness. }\end{array}$} & 870 & 148 & 42 & 20 & 5 & 1085 & 4.520 & 0.102 \\
\hline & & 174 & 37 & 14 & 10 & 5 & 240 & & \\
\hline & & $62 \%$ & $21 \%$ & $8 \%$ & $6 \%$ & $3 \%$ & $100 \%$ & & \\
\hline \multirow[t]{3}{*}{2} & \multirow{3}{*}{$\begin{array}{l}\text { Internet effectiveness } \\
\text { shows the ability to } \\
\text { access information } \\
\text { quickly and easily. }\end{array}$} & 770 & 228 & 36 & 22 & 6 & 1062 & 4.425 & 0.088 \\
\hline & & 154 & 57 & 12 & 11 & 6 & 240 & & \\
\hline & & $50 \%$ & $33 \%$ & $7 \%$ & $6 \%$ & $5 \%$ & $100 \%$ & & \\
\hline \multirow[t]{3}{*}{3} & \multirow{3}{*}{$\begin{array}{l}\text { All Enugu metropolis } \\
\text { employees enjoys more } \\
\text { value on internet } \\
\text { effectiveness. }\end{array}$} & 790 & 204 & 66 & 14 & 2 & 1076 & 4.483 & 0.098 \\
\hline & & 158 & 51 & 22 & 7 & 2 & 240 & & \\
\hline & & $53 \%$ & $29 \%$ & 13)\% & $4 \%$ & $1 \%$ & $100 \%$ & & \\
\hline \multirow[t]{4}{*}{4.} & \multirow{3}{*}{$\begin{array}{l}\text { It improve internal } \\
\text { communication via } \\
\text { email, connected } \\
\text { calendar and chart }\end{array}$} & 825 & 136 & 60 & 24 & 9 & 1054 & 4.392 & 0.093 \\
\hline & & 165 & 34 & 20 & 12 & 9 & 240 & & \\
\hline & & $57 \%$ & $19 \%$ & $11 \%$ & $7 \%$ & $5 \%$ & $100 \%$ & & \\
\hline & Grand Mean & & & & & & & 4.455 & 0.0955 \\
\hline
\end{tabular}

This table shows that the respondents indicated their option on which internet effectiveness influence small and medium enterprises business expansion in Enugu metropolis. The research items 1,2,3,4,5 have mean score of above 4.0point respectively and it was rated great extent by respondents. The study showed that internet effectiveness has a significant effect on small and medium enterprises business expansion in Enugu metropolis, Enugu Nigeria since grand mean (4.455) is greater than cut-off mean (3.00).

Question Two: What is the extent at which internet convenience influence small and medium enterprises quality of job delivery in Enugu metropolis?

Table 3 Mean rating of responses of respondents on the extent at which internet convenience influence small and medium enterprises quality of job delivery in Enugu metropolis

\begin{tabular}{|l|l|c|c|c|c|c|c|l|l|}
\hline S/N & Questionnaire Item & VHE(5) & HE(4) & M(3) & LE(2) & VLE(1) & Total & Mean & SD \\
\hline \multirow{2}{*}{1} & Internet as a delivery channel is based & 835 & 188 & 42 & 14 & 5 & 1084 & 4.517 & 0.101 \\
& on the expected reduction in overhead & 167 & 47 & 14 & 7 & 5 & 240 & & \\
& expenses & $5 \%$ & $27 \%$ & $8 \%$ & $4 \%$ & $3 \%$ & $100 \%$ & & \\
\hline 2 & The unit cost of internet fall more & 860 & 228 & 21 & 6 & 1 & 1116 & 4.650 & 0.115 \\
& rapidly than those of traditional bank & 172 & 57 & 7 & 3 & 1 & 240 & & \\
& & $61 \%$ & $33 \%$ & $4 \%$ & $2 \%$ & $1 \%$ & $100 \%$ & & \\
\hline \multirow{2}{*}{3} & Internet delivery is informational and & 790 & 204 & 66 & 14 & 2 & 1076 & 4.483 & 0.098 \\
& transactional & 158 & 51 & 22 & 7 & 2 & 240 & & \\
& & $53 \%$ & $29 \%$ & $13 \%$ & $4 \%$ & $1 \%$ & $100 \%$ & & \\
\hline
\end{tabular}




\begin{tabular}{|l|l|c|c|c|c|c|c|c|c|}
\hline 4 & Internet offer all sort of financial & 830 & 132 & 60 & 24 & 9 & 1055 & 4.396 & 0.089 \\
& product and engage in a wide variety & 166 & 33 & 20 & 12 & 9 & 240 & & \\
& of financial business & $58 \%$ & $19 \%$ & $11 \%$ & $7 \%$ & $5 \%$ & $100 \%$ & & \\
\hline & Grand Mean & & & & & & 4.512 & 0.300 \\
\hline
\end{tabular}

Table 3 shows that the respondents indicated their option on the extent at which internet convenience influences small and medium enterprises quality of job delivery in Enugu metropolis, Enugu Nigeria. The research items 1,2,3,4,5 have mean score of above 4.0point respectively and it was rated great extent by respondents. The study showed that internet convenience has significant effect on small and medium enterprise quality of job delivery in Enugu metropolis, since grand mean (4.512) is greater than cut-off mean (3.00).

\subsection{Test of Hypotheses}

The three hypotheses were formulated for this study and will be tested and a decision taken is based on the rule below.

Decision rule: Reject Hi if P-value $>0.01$

\subsubsection{Test of Hypothesis One}

$\mathrm{H}_{1}=$ Internet effectiveness has no significant effect on small and medium enterprises business expansion in Enugu metropolis.

\begin{tabular}{|c|c|c|c|c|c|c|c|}
\hline \multicolumn{8}{|c|}{ Model Summary } \\
\hline $\begin{array}{c}\text { Mode } \\
1\end{array}$ & $\mathbf{R}$ & $\begin{array}{c}\mathbf{R} \\
\text { Square }\end{array}$ & \multicolumn{2}{|c|}{$\begin{array}{l}\text { Adjusted R } \\
\text { Square }\end{array}$} & \multicolumn{3}{|c|}{ Std. Error of the Estimate } \\
\hline 1 & $.947^{a}$ & .897 & \multicolumn{2}{|c|}{.897} & \multicolumn{3}{|c|}{.33681} \\
\hline \multicolumn{8}{|c|}{ a. Predictors: (Constant), Internet Effectiveness } \\
\hline \multicolumn{8}{|c|}{ ANOVA $^{\mathrm{a}}$} \\
\hline \multicolumn{2}{|c|}{ Model } & \multicolumn{2}{|c|}{ Sum of Squares } & df & \multirow{2}{*}{$\begin{array}{l}\text { Mean Square } \\
171.551\end{array}$} & $\mathrm{~F}$ & Sig. \\
\hline \multirow[t]{3}{*}{1} & Regression & \multicolumn{2}{|c|}{171.551} & 1 & & $\begin{array}{l}1512.20 \\
8\end{array}$ & $.000^{\mathrm{b}}$ \\
\hline & Residual & \multicolumn{2}{|l|}{19.626} & 173 & .113 & & \\
\hline & Total & 191.177 & & 174 & & & \\
\hline \multicolumn{8}{|c|}{ a. Dependent Variable: SMEs business expansion } \\
\hline \multicolumn{8}{|c|}{ b. Predictors: (Constant), Internet Effectiveness } \\
\hline
\end{tabular}

\begin{tabular}{|c|c|c|c|c|c|c|}
\hline \multicolumn{7}{|c|}{ Coefficients $^{\mathbf{a}}$} \\
\hline & & \multicolumn{2}{|c|}{$\begin{array}{l}\text { Unstandardized } \\
\text { Coefficients }\end{array}$} & \multirow{2}{*}{$\begin{array}{r}\begin{array}{l}\text { Standardized } \\
\text { Coefficients }\end{array} \\
\text { Beta } \\
\end{array}$} & \multirow[b]{2}{*}{$\mathrm{t}$} & \multirow[b]{2}{*}{ Sig. } \\
\hline \multicolumn{2}{|c|}{ Model } & $\mathrm{B}$ & Std. Error & & & \\
\hline \multirow[t]{2}{*}{1} & (Constant) & .057 & .110 & & .515 & .607 \\
\hline & Internet Effectiveness & .957 & .025 & .947 & 38.887 & .000 \\
\hline
\end{tabular}

In testing this hypothesis, internet effectiveness was regressed against small and medium enterprises business expansion. The result of the single-regression analysis showed the model to examine the effect of internet effectiveness on small and medium enterprises. 


\subsection{Small and Medium Enterprises Business expansion $=0.057+0.957$ internet effectiveness}

The empirical result showed that the coefficient of internet effectiveness has positive effect on small and medium enterprises business expansion; it means that internet effectiveness has positive and direct effect on small and medium enterprises business expansion. The results of the $t-$ statistics denoted that the coefficient was statistically significance. This is because observed values of $t$ - statistics (38.887) is greater than its P-values (0.000). The results of the $F-$ statistical test showed that the overall regression of the hypothesis one was statistically significance. This was because observed value of the F - statistics (1512.208) was greater than its P-value (0.000). Again, our empirical result showed that the Pearson product moment correlation analysis (r) was 0.947 . The strength of relationship between the two variables was high. However, we rejected the null hypothesis and concluded that internet effectiveness has significant effect on small and medium enterprises business expansion in Enugu metropolis, Enugu Nigeria.

\subsection{Test of Hypothesis Two}

$\mathrm{H}_{2}=$ Internet convenience has no significant effect on small and medium enterprises quality of job delivery in Enugu metropolis.

\begin{tabular}{|c|c|c|c|c|}
\hline \multicolumn{5}{|c|}{ Model Summary } \\
\hline Model & $\mathbf{R}$ & $\begin{array}{c}\text { R } \\
\text { Square }\end{array}$ & $\begin{array}{c}\text { Adjusted R } \\
\text { Square }\end{array}$ & $\begin{array}{c}\text { Std. Error of the } \\
\text { Estimate }\end{array}$ \\
\hline 1 & $.931^{\mathrm{a}}$ & .866 & .865 & .26055 \\
\hline \multicolumn{5}{|l}{ a. Predictors: (Constant), Internet Convenience } \\
\hline
\end{tabular}

\begin{tabular}{|c|c|c|c|c|c|c|c|}
\hline \multicolumn{8}{|c|}{ ANOVAa } \\
\hline & Model & $\begin{array}{c}\text { Sum of } \\
\text { Squares }\end{array}$ & df & $\begin{array}{l}\text { Mean } \\
\text { Square }\end{array}$ & & $\mathbf{F}$ & Sig. \\
\hline \multirow[t]{3}{*}{1} & Regression & 75.936 & 1 & 75.936 & \multicolumn{2}{|c|}{$\begin{array}{c}1118.60 \\
4\end{array}$} & $.000^{\mathrm{b}}$ \\
\hline & Residual & 11.744 & 173 & .068 & & & \\
\hline & Total & 87.680 & 174 & & & & \\
\hline \multicolumn{8}{|c|}{ a. Dependent Variable: SMEs Quality of job delivery } \\
\hline \multicolumn{8}{|c|}{ b. Predictors: (Constant), Internet Convenience } \\
\hline \multicolumn{8}{|c|}{$\begin{array}{cc}\text { Coefficients }^{\mathrm{a}} \\
\end{array}$} \\
\hline \multirow{2}{*}{\multicolumn{2}{|c|}{ Model }} & \multicolumn{2}{|c|}{$\begin{array}{c}\text { Unstandardized } \\
\text { Coefficients }\end{array}$} & \multicolumn{2}{|c|}{$\begin{array}{c}\text { Standardized } \\
\text { Coefficients }\end{array}$} & \multirow[b]{2}{*}{ t } & \multirow[b]{2}{*}{ Sig. } \\
\hline & & B & $\begin{array}{l}\text { Std. } \\
\text { Error }\end{array}$ & Beta & & & \\
\hline \multirow[t]{2}{*}{1} & (Constant) & 1.614 & .089 & & & 18.111 & $\begin{array}{c}.00 \\
0\end{array}$ \\
\hline & $\begin{array}{l}\text { Internet } \\
\text { Convenience }\end{array}$ & .670 & .020 & \multicolumn{2}{|l|}{.931} & 33.446 & $\begin{array}{c}.00 \\
0 \\
\end{array}$ \\
\hline
\end{tabular}

In testing this hypothesis, internet convenience was regressed against small and medium enterprises quality of job delivery. The result of the single-regression analysis showed the model to examine the effect of internet convenience on small and medium enterprises quality of job delivery.

\subsection{Small and medium enterprises quality of job delivery $=1.614+0.670$ Internet convenience}

The empirical result showed that the coefficient of internet convenience has positive effect on small and medium enterprises quality of job delivery; it means that internet convenience has positive and direct influence on small and medium enterprises quality of job delivery. The results of the $t$ - statistics denoted that the coefficient of internet 
convenience was statistically significance. This is because observed values of $t$ - statistics (33.446) was greater than its $\mathrm{P}$-values (0.000). The results of the $\mathrm{F}$ - statistical test showed that the overall regression of the hypothesis two was statistically significance. This was because observed value of the F - statistics (1118.604) was great than its P-value (0.000). Again, our empirical result showed that the Pearson product moment correlation analysis (r) was 0.931 . The strength of relationship between the two variables was high. However, we rejected the null hypothesis and concluded that internet convenience has significant effect on small and medium enterprises quality of job delivery in Enugu metropolis.

\subsection{Summary of Findings}

The following are the major findings of the study:

- The findings of the study revealed that internet effectiveness has significant effect on small and medium enterprises business expansion in Enugu metropolis since internet effectiveness shows the ability to access information quickly and easily. ( $\mathrm{t}$ - statistics (38.887) $>\mathrm{P}$ - value $(0.000)$.

- The findings of the study revealed that internet convenience has significant effect on small and medium enterprise quality of job delivery in Enugu metropolis, since the unit cost of internet fall more rapidly than those of traditional bank ( $\mathrm{t}$ - statistics (33.446) > P - value (0.000).

\section{Conclusion}

The study concludes that internet banking has a significant impact on small and medium enterprise performance in Enugu Metropolis. The finding of the study was of greatly important to the management of small and medium enterprises (SMEs) as they shed light on effects of adoption of internet banking on how small and medium enterprises perform, this assisted them in formulating strategies that would assist in the adoption of internet banking by Small and medium enterprises in Enugu metropolis. The findings of the study shows that internet banking proxies such as effectiveness, convenience, accessibility and efficiency contributed significantly to the performance of small and medium enterprises in Enugu metropolis. Internet effectiveness shows the ability to access information quickly and easily. Base on the findings of this study it show that the effect of internet banking on the performance of small and medium enterprises in Enugu metropolis is significant. The finding also shows that internet banking has increased customer base because of easy method of payments, more time to carry out other business activities, easy access to funds in the bank, increased business transactions, increased profits and increased business efficiency.

\section{Recommendations}

Based on the findings of this study, the following recommendations were made.

- Small and medium enterprises should continue to adopt internet banking since it effects tremendously on their operational performance. The government should improve the technological base of the country and engage in technological awareness in areas that have not experienced much technological effects. This is to make them see the need for the adoption of technology, and how it makes banking easier.

- Small and medium enterprises is advised to organize training on internet banking from time to time for the benefit of its customers, this will go a long way to enhance the benefits derived by the bank from internet banking.

\section{Compliance with ethical standards}

\section{Disclosure of conflict of interest}

No conflict of interest among the Authors.

\section{Statement of informed consent}

Informed consent was obtained from all individual participants included in the study.

\section{References}

[1] Abubakar A. The effect of electronic banking on growth of deposit money banks in Nigeria. European journal of business management. 2014; 6(33): 79-89. 
[2] Berger AN. The Economic Effect of Technological progress: Evidence from the banking Industry. Journey of money, Credit and Banking. 2003; 35(2): 141- 176.

[3] Susanto RJ, Azis AM, Irjayanti M. Pelatihan Penggunaan Komputer dan Penggunaan Media Social Berbasis Internet. Journal Dharma Bhakti STIE Ekuitas. 2016; 1(1): 28-31.

[4] Irjayanti M, Azis AM. Knowledge Management for Banking Industry Continuous Improvement. Journal technology. 2013; 1(2): 55-59.

[5] Suriya M, Mahalakshmi V, Karthik R. A study on customer perception towards internet banking. International Journal of Sales \& Marketing Management Research and Development. 2012; 2(3): 15-34.

[6] Chang, Hamid. A Study on Customer Perception Towards Internet Banking: Identifying Major Contributing Factors. The Journal of Nepalese Business Studies. 2010; 5(1): 101-111.

[7] Alsajja, Dennis. E-banking in Emerging Economy: Empirical Evidence of Iran. International Journal of Economics and Finance. 2010; 2(1): 201-209.

[8] Gerrard, Cunningham. Factors affecting the adoption of Internet Banking in Hong Kong-- implications for the banking sector .International Journal of Information Management. 2003; 27(5): 336-351.

[9] Kim BM, Widdows R, Yilmazer T. The Determinants of Consumers' Adoption of Internet Banking: Factors Determining Consumer Adoption of Internet Banking (2006). Retrieved on July, 2010 from World Wide Web:

[10] Arunachalam, Sivasubramanian. Electronic Commerce: A Managerial Perspective. New Jersey: prentice Hall. Electronic commerce journal research. 2007; 2(4): 26-27.

[11] Agwu MO, Emeti. Issues, challenges and prospects of small and medium scale enterprises (SMEs) in PortHarcourt City. European Journal of Sustainable Development. 2014; 3(1): 101-114.

[12] Mbah S, Obiezekwem J. Electronic Banking and Performance of Small and Medium Scale Enterprises in Anambra State, Nigeria. International Journal of Business and Management. 2019; 14(6): 173-180.

[13] Orga JI, Ibeme NP, Ekwochi EA. An Overview of Challenges and Survival Strategies of Small Scale Businesses in Enugu Metropolis (A Study of Selected Small Scale Businesses). IAA JOURNAL OF SOCIAL SCIENCES. 2020; 6(1): 91-99.

[14] Tomovska, AM, Makedonka, D Jadranka, M. Drivers of entrepreneurial intentions among business students in Macedonia, Economic Research-Ekonomska Istraživanja, (2016); 29:1, 1062-1074,

[15] Mbah S, Obiezekwem J. Electronic banking and performance of small and medium scale. International journal of management sciences. 2019; 4(6): 167-1.

[16] Njoku CO, Nwadike EC, Azuama GU. Effect of Electronic Banking on the Economic Growth of Nigeria (2009-2018). The International Journal of Business Management and Technology. 2020; 4(3): 196-291.

[17] Dedi SS, Agil FI, Putri A. Effect of Internet Banking on E-Commerce. Advances in Economics, Business and Management Research. 2019; 112(20): 22-23.

[18] Masocha R, Dzomonda O. Adoption of mobile money services and the Performance of small and medium Enterprises in zimbabwe, Academy of Accounting and Financial Studies. 2018; 22(3): 56-77.

[19] Muchiri JW. Effect of mobile banking adoption on the performance of small and medium enterprises in Nairobi country. International Journal of Economics, Business and Management Research. 2018; 2(4): 445-486. 